\title{
The Use Of Expressive Speech Acts In Hannah Montana Session 1
}

\author{
Nur Vita Handayani \\ Ahmad Dahlan University \\ pearhandayani@gmail.com
}

\begin{abstract}
This study aims to describe kinds and forms of expressive speech act in Hannah Montana Session 1. It belongs to descriptive qualitative method. The research object was expressive speech act. The data source was utterances which contain expressive speech acts in the film Hannah Montana Session 1. The researcher used observation method and noting technique in collecting the data. In analyzing the data, descriptive qualitative method was used. The research findings show that there are ten kinds of expressive speech act found in Hannah Montana Session 1, namely expressing apology, expressing thanks, expressing sympathy, expressing attitudes, expressing greeting, expressing wishes, expressing joy, expressing pain, expressing likes, and expressing dislikes. The forms of expressive speech act are direct literal expressive speech act, direct nonliteral expressive speech act, indirect literal expressive speech act, and indirect non-literal expressive speech act.
\end{abstract}

Keywords: Pragmatics, Expressive, Speech Act, Direct, Indirect. 


\begin{abstract}
Abstrak
Penelitian ini bertujuan untuk mendeskripsikan jenis dan bentuk ekspresif tindak tutur dalam Hannah Montana Sesi 1. Ini milik deskriptif metode kualitatif. Objek penelitian adalah ekspresif tindak tutur. Sumber data adalah ucapan-ucapan yang mengandung tindak tutur ekspresif dalam film Hannah Montana Session I. Peneliti menggunakan metode observasi dan teknik mencatat dalam mengumpulkan data. Dalam menganalisis data, metode deskriptif kualitatif digunakan. Hasil penelitian menunjukkan bahwa ada sepuluh jenis tindak tutur ekspresif ditemukan di Hannah Montana Sesi 1, yaitu mengungkapkan permintaan maaf, mengungkapkan terima kasih, mengekspresikan simpati, mengungkapkan sikap, mengungkapkan ucapan, mengungkapkan keinginan, mengekspresikan sukacita, mengekspresikan rasa sakit, mengungkapkan suka, dan mengekspresikan tidak suka. Bentuk-bentuk ekspresif tindak tutur yang langsung literal tindak tutur ekspresif, langsung non-literal ekspresif tindak tutur, langsung literal ekspresif tindak tutur, dan tidak langsung non-literal ekspresif tindak tutur.
\end{abstract}

Kata kunci: Pragmatik, Tindak Tutur Ekspresif, Langsung, Tidak Langsung.

\title{
Introduction
}

Communication is important as human being. It is a life skill, people as social being need to communicate to the others, share ideas, express their feeling and their emotion and has interaction to meet their needs. By understanding the language and the meaning of it people connected to each other. The utterances performed by the speaker are an 
action or activities which may contain words expressed their feeling. In this case, it is called expressive speech act. Expressive speech act can be direct and indirect. As literary work, film also contains expressing feeling. Thus, this paper would give more understanding in expressive speech act and direct and indirect expressive speech act uttered in Hannah Montana Session 1.

Yule (1996: 3) states that "pragmatics is concerned with the study of meaning as communicated by speaker (or writer) and interpreted by a listener (or reader)". It has to do with the meaning in interaction between the speaker and the hearer. To reach the speaker's interpretation, the hearer has to understand the utterance rather than words and phrase themselves. It is more than understanding the speaker but also what the speaker's imply. In addition, context also influences what the speaker's imply. Context such as when, where, what situation, who they are talk to, in what circumstances are necessary to involves helping the hearer interprets the speaker's meant (idem: 3).

Yule (1996: 47) states speech act as action performed via utterances. Like it is called, speech is the utterance and act is an action. As Austin says it is not only saying something, the speaker is also doing something. Thus, it is more than describing the word. It is used to communicate, to pass the information, more than that it carries mutual acting between the speaker and the hearer.

One of the aspects studied in pragmatics is speech act. Yule (1996: 47) defines speech act as the action performed by a speaker with an utterance. In other word, there are activities intended to do by speaker by saying something. Speech act firstly is delivered by Austin (1962: 103) which is divided in three different acts, those are, locutionary act, 
illocutionary act, and perlocutionary act. Austin (1962: 99) defines illocutionary act as performance of an act in saying something. By saying the utterances, the speaker is also doing a certain action. Searle (1976: 1012) distinguishes five classes of illocutionary acts and bases on illocutionary point, the result of illocutionary point and the relationship of word and world. They are assertive, directives, commissives, expressive, and declarations.

Searle (1976: 12) states expressive to mentions behabitive by Austin. It is used to express the psychological state in sincerity condition about a state of affair in specified in the propositional content. Including the expressive speech act are welcoming, praising, blaming, etc. Yule (1996: 53) states that expressive can be a statement of pleasure, pain, like, dislike, joy, or sorrow. It means expressive tell about speaker's feeling.

The expressive speech act can be direct and indirect, literal and non-literal, implicit and explicit (Meyer 2009: 50). Combining the literalnon literal and direct -indirect, there are four ways of performing expressive speech act (Wijana: 1996: 33).

1. Direct Literal Speech Act

Direct literal speech act is the speech act expressed the word literally and communicates directly. Thus, statement expressed in declarative sentence, question expressed in interrogative, command, request expressed imperative. 


\section{Direct Non literal Speech Act}

In contrast, direct non literal speech act is the speech act expressed by the sentence mode suitable for the purpose of speech, but the composition of the words do not have the same meaning with the intention of speaker. Thus, the speaker does not mean as the word mean. In this speech act, the speaker means to criticize by declarative sentence.

3. Indirect Literal Speech Act

Indirect literal speech act is the speech act expressed in a sentence mode, the meaning that is contrary with the purpose that it is expressing, even though the meaning of the words are arranged in accordance with what the speaker intended. It has different form and function which is not compatible.

4. Indirect Non Literal Speech Act

Indirect non literal speech act is the speech act that when expressed by sentence mode the meaning of the sentence is incompatible with the intention of the speaker.

\section{Research Method}

In this research, the researcher used descriptive qualitative research. Dörnyei (2007: 24) says that qualitative research is a research involves data collection procedures that result primarily in open-ended, non-numerical data which is then analyzed primarily by non-statistical methods. In addition, Neville (2007: 3) states qualitative research is suitable for observe the disciplines of language and consider its place within social sciences and humanities more generally.

The object of this research is the dialogue of the movie characters using expressive speech act. Data in this research is the dialogue that 
contain expressive speech act. Data source is a basic information and material that collected by the researcher. It can be in the form of document, thing, person, action, film, official document, etc. Data source of this research is film Hannah Montana Session 1 episode 1-2. According to Mahsun (2005: 92-104) there are three methods of gathering data. In this research, the researcher used metode simak (observing method) because the data are in the form of spoken language that obtained in a film Hannah Montana Session 1 episode 1-2. Thus this research used noting technique (metode catat) in collecting expressive speech act. The researcher observing the film then write the expressive speech act found and in which situation. In this research, the researcher used qualitative and descriptive method to analyze and interpret the kinds of expressive in Hannah Montana Session 1.

\section{Discussion}

According to data analyzing in Hannah Montana Session 1 episode 1-2 the researcher found some expressive speech acts. They are expressing apology, expressing thanking, expressing sympathy, expressing attitudes, expressing greeting, expressing wishes, expressing joy, expressing pain, expressing likes, and expressing dislike.

\section{Kinds of Expressive Speech Act Used in Hannah Montana Session 1.}

1. Expressing Apology
a. Hannah
: Oh, I'm sorry, Fermine.
Fermine : Is okay, I kiss it. (Kisses his finger) All better.....

The data (a) can be identified for expressing apology. Fermine is Hannah's designer. He makes a dress for Hannah for the next show. 
Fermine is hurting his finger while working on Hannah's wearing dress. She forgets that Fermine sew the dress she wore. Hannah feels regrets to Fermine for keeping moving. The apologizing expression is implicit because the verb am does not fit the structure performative verb; the naming of speech act conveyed in the adjective sorry.

\section{Expressing Thanks}

Thanking expresses that the speaker is pleased about or grateful for something that another people have done. The performative verb that describes this feeling is thanked, as shown in the data below:

b. Robby Ray : Son, I primped your ride. Jackson : Oh, yes, he did! (Laughing) Oh! Thank you, thank you! Thank you! Thank you! Thank you! Thank you! Robby Ray: Okay, Son, you can let go now. It was cute when you were five, now it just throws my back out.

The verb thank refers to this classification. The utterance in (b) is used by Jackson to thanked Robby Ray for fixing his car.

\section{Expressing Resentment}

Resentment refers to the verb resent. Resentment is statement to expressing angry because you have been forced to accept someone or something that you do not like.

In this situation, Miley had fight with Lilly because Lilly was desperate to show Hannah's stuff to the other friends. Miley disbelieved that Lilly wanted to do that which means Miley's secret as a popular singer Hannah Montana will be revealed. After Lilly went home, Miley tells to her father which also knows that her secret being revealed.

\section{c. Miley: I am so mad!}


Robby Ray: So you're gonna take it out on my ice cream sundae? You wanna talk about it?

The data (c) expresses the speaker's feeling. The resentment shows in the adjective mad which is mean angry.

\section{Expressing Greeting}

Greeting is something friendly or polite that you say or do when meet or welcome someone. This expression shows that you are pleased that they are with you.

d. Johnny: (walking over) Hey, Miley. How's it going?

Miley : Um, pretty good! Just getting some ketchup for my veggie burger. I see you like mayonnaise. Never tried that on a veggie burger! And maybe I should, but, not today because then the ketchup would go all over the kitchen.

Johnny comes over to Hannah that is getting some ketchup in her burger at the cafetaria. Johnny greets Hannah Montana friendly by saying Hey, Miley How's it going? Those words are used to welcome Hannah. The Hannah's answer also reflected that the speaker intended to do greeting even though she is nervous in speaking.

5. Expressing Joy

The performative verbs that denote this action is rejoice, brighten, swoon, delight, amuse, please, satisfy, enjoy, and exult.

e . Robby Ray : And are you happy about that? Jackson : Yes I am! Dad, it's mine. It's not perfect but it's my own car, and I bought it with my own money. 
Considering data (e) Jackson answering Yes I am with happily for Robby Ray's question which means that he was happy. The reason is because he bough new car with his own money.

\section{Direct and Indirect Expressive Speech Act Found in Movie}

1. Literal Direct Strategy

A speech act can be performed direct if its intent is clearly conveyed by the words and structure of the utterance. The direct speech act can be literal if the speaker means what she or he says.

f. Lilly : (following) what's wrong with your voice?

Hannah : Um, that happens after every concert. (Moving the rack)

Lilly : (spreading clothes apart) You give so much. I just wish Miley were here.

Hannah : (hidden behind the moving rack) Uh, Miley, who's Miley? I don't know Miley, that's a strange name.

g. Oliver: Take it off, dude! Take it off! Take it off! Take it off! Friend : Dude, what's with you and the gum chewing?

Oliver : (think back: Aunt Harriet: Oh, little baby Ollie. Aunt Harriet just wants to eat you up.You're so yummy, yummy, yummy. (Baby crying)

Oh... Let me get that off you)

Oliver : (GRUNTING) I hate that woman.

h. Fermine: (leaving through the front door) I love you, Hannah Montana.

The above data (f), (g), and (h) are in the form of declarative, as a direct speech act, those would be used to make a statement. The performative verbs such as wish, hate, and love are in declarative sentences which are used to make statements not questions, commands or requests. It uses to express action or opinion. The data have literal meaning because 
it means like word means. The utterance in (f) means a wish that Miley can join with Lily to see Hannah's concert because she is Hannah's big fan. Unfortunately, Miley who is Lily's best friend refuses it. She feels disappointed. The word wish literally means hope that her friend can see the Hannah Montana together with her.

The utterance in $(\mathrm{g})$ showed that the speaker hates with his aunt Harriet. It has a literal meaning which means the speaker; Oliver does not like Aunt Harriet. It can be seen that the hate of gum chewing is started when he was a child. He remembers at that time his aunt chewed her gum but it dropped to her. The way she is chewing and that disgusting dropped gum makes Oliver hate his Aunt. It was sounding in hate tone. In the utterance (h) Fermine, the speaker wants to show like or love the hearer before he leaves Hannah's home. When the speaker's intended has the same aims as the words means, thus, the above data used literal direct strategy to perform the utterance.

\section{Non-literal Direct Strategy}

A speech act can be performed direct if its intent if the words and structure of the utterance agree with its function. The direct speech act can be non- literal if the speaker does not mean what she or he says or the word does not mean like the word say.

i. Robby Ray: I don't know, maybe it wanted to party. Oh, come on, Dontzig, just trying to be neighborly.

Dontzig : That's nice, but I hate neighbors. That's why I got the big hedge. So, something needs to be done about this. 
Robby Ray: Yeah, and I think something needs to be done about this (pointing Dontzig belly). I would recommend possibly some sit-ups or maybe a bigger robe.

Dontzig : :Ha, ha. Very neighborly... Oh, got a new car.

You know my wife, she had a car just like this. Traded it in. She thought it was too girly.

In this case, the speaker utters non literal act that very neighborly here means the opposite not neighborly. Literally, very neighborly is friendly or helpful but it is used by Dontzig to criticize Robby Ray who asks her to be neighborly at first. The data (i) are in the form of declarative and the function is to make a statement so the data (i) belong to non- literal direct strategy.

\section{Literal Indirect Strategy}

In the indirect act if wherever there is an indirect relation between structure and function. The indirect speech act can be literal if the speaker means what she or he says.

j. Lilly : Miley, don't make me go see my favorite singer without my best friend. If you don't take this ticket, I'm going to end up going to the concert with Mr. Hannah Montana. (points at Oliver)

Oliver : (standing again) You have an extra ticket to Hannah Montana! (The entire cafeteria turns in their direction - he sinks low in his chair) That was really loud, wasn't it? They disappear from view as their table is swarmed by rabid Hannah Montana fans. (Back at the 
Stewart house, Jackson comes down the stairs and enters the kitchen.

In this case, the speaker utters literal meaning that he speaks too loud. The data ( $\mathrm{j}$ ) is not intended to question the way he speaks but it is used to making a statement of blaming on what he did. It is because he realizes that he was wrong by speaking too loud and making Hannah Montana's fans swarmed them to see the ticket. The utterance used indirect strategy in performing the utterances. The form of the utterances is tag question using falling intonation but it is not used to make sure that he speaks to loudly. It is used to make a statement of blaming.

\section{Non-Literal Indirect Strategy.}

In the indirect act if wherever there is an indirect relation between structure and function of the utterances. Non- literal meaning is if the speaker does not means what she or he said.

k. Dontzig : So, Stewart family, what would another leaves from your tree be doing in my hot tub?

Robby Ray: I don't know, maybe it wanted to party. Oh, come on, Dontzig, just trying to be neighborly.

The utterance which is spoken by Dontzig has functioned to make a statement rather than a question. Thus, there is indirect relation between the structure and function. The structure is interrogative, but it is used to make a statement of blaming. The utterances have non literal meaning; it does not mean that the leaves can do something in the hot tub. It is used a figurative language which supposed a non-living thing act like a living things. Thus, this data $(\mathrm{k})$ belongs to Non-literal indirect strategy 


\section{Conclusion}

Based on the result of this study, the researcher can draw some conclusions about the kinds of expressive speech act used by the character of Hannah Montana Session 1. It can be classified as expressing apology, expressing thanking, expressing sympathy, expressing attitude, expressing greeting, expressing wishes, expressing joy, expressing pain, expressing like, expressing dislikes. The researcher found the use of direct literal expressive speech act, indirect literal expressive speech act, direct nonliteral expressive speech act, and indirect non- literal expressive speech act.

\section{References}

Austin, J.L. 1962. How to Do Things with Words. London: OUP

Dörnyei, Zoltán. 2007. Research Methods in Applied Linguistics. Oxford: Oxford University Press.

Mahsun, M. S. 2005. Metode Penelitian Bahasa: Tahapan strategi. Metode, dan tekniknya. Jakarta: Rajawali Press

Meyer, Charles F.2009. Introducing English Linguistics. Cambridge: Cambridge University Press.

Neville, Collin. 2007. Introduction to Research and Research Methods. Bradford: University of Bradford 
The Use of Expressive Speech Acts In Hannah Montana Session 1

Searle, John R. 1976. A Classification of Illocutionary Act. Languange in Society, Vol. 5, No.1. (April, 1976), pp 1-23.London: CUP

Wijana. I Dewa Putu. 1996. Dasar- Dasar Pragmatik. Yogyakarta: ANDI Yule, George. 1996. Pragmatics. Oxford: Oxford University Press. 